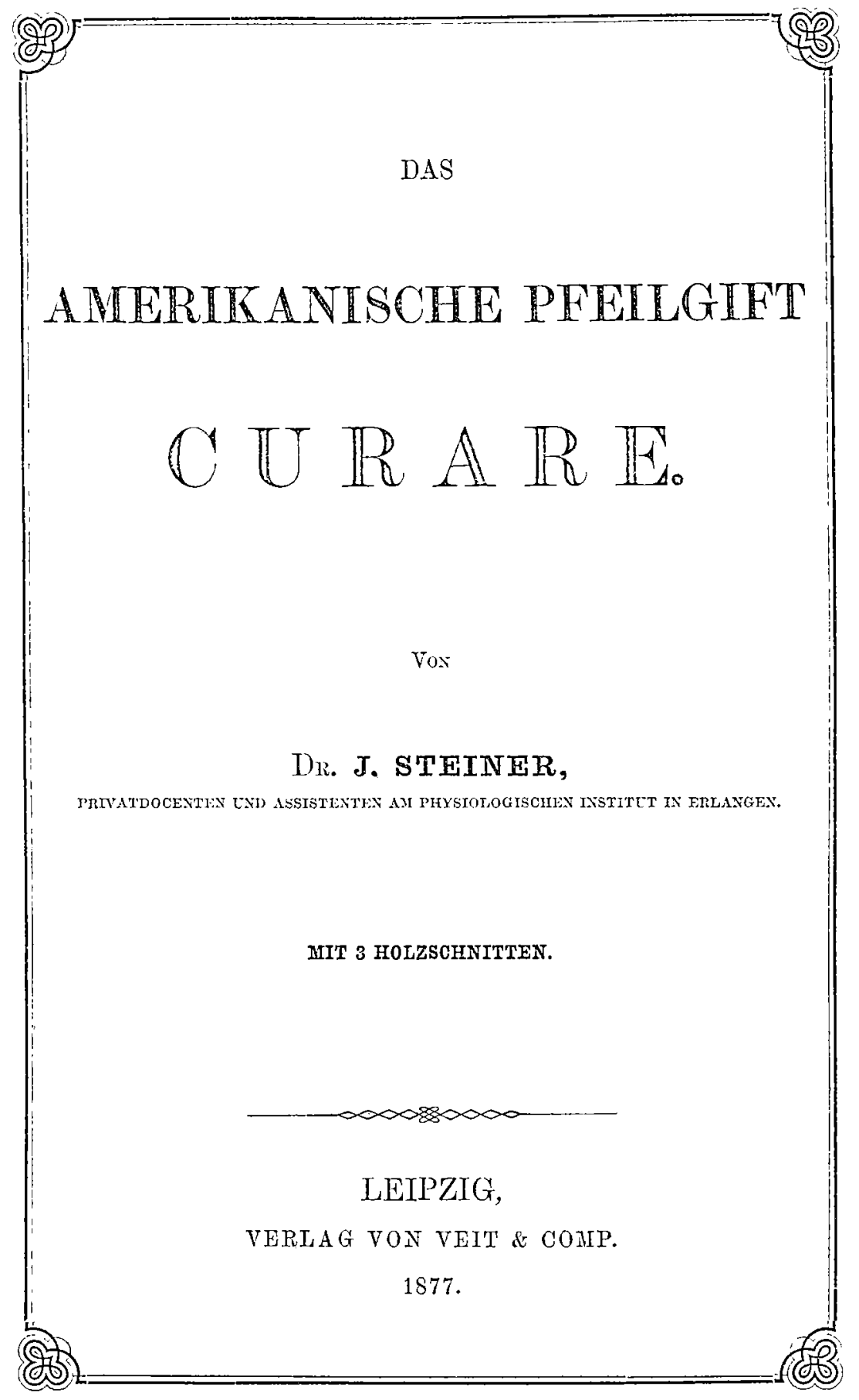



DAS

\title{
AMERIKANISCHE PFEILGIFT
}

\author{
$\mathbb{C} \mathbb{U} \mathbb{R} \mathbb{R} \mathbb{E}$.
}

VoN

DR. J. STEINER,

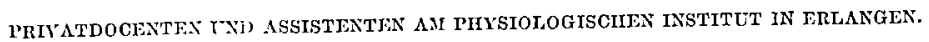

MIT 3 HOLZSCHNITTEN.

\section{LEIPZIG,}

VERLAG VON VEIT \& COMIP.

1877. 
